\title{
Variability of conch morphology in a cephalopod species from the Cambrian to Ordovician transition strata of Siberia
}

\author{
Jerzy Dzik \\ Acta Palaeontologica Polonica 65 (1), 2020: 149-165 doi:https://doi.org/10.4202/app.00674.2019
}

A block of stromatolitic limestone found on the Angara River shore near Kodinsk, Siberia, derived from the exposed nearby Ust-kut Formation, has yielded a sample of 146 ellesmeroceratid nautiloid specimens. A minor contribution to the fossil assemblage from bellerophontid and hypseloconid molluscs suggests a restricted abnormal salinity environment. The associated shallow-water low diversity assemblage of the conodonts Laurentoscandodus triangularis and Utahconus(?) eurypterus indicates an age close to the Furongian-Tremadocian boundary. Echinoderm sclerites, trilobite carapaces, and hexactinellid sponge spicules were found in another block from the transitional strata between the Ust-kut and overlying terrigenous Iya Formation; these fossils indicate normal marine salinity. The conodont L. triangularis is there associated with Semiacontiodus iowensis and Cordylodus angulatus. This means that the stromatolitic strata with cephalopods are older than the early Tremadocian $C$. angulatus Zone but not older than the Furongian C. proavus Zone. The sample of nautiloid specimens extracted from the block shows an unimodal variability in respect to all recognizable aspects of their morphology. The material is probably conspecific with the poorly known Ruthenoceras elongatum from the same strata and region.

Key words: Cephalopoda, Nautiloidea, Endoceratida, Ellesmeroceratina, evolution, Furongian, Tremadocian, Russia.

Jerzy Dzik [dzik@twarda.pan.pl], Institute of Paleobiology, Polish Academy of Sciences, Twarda 51/55, 00-818 Warszawa, Poland and Faculty of Biology, Biological and Chemical Centre, University of Warsaw, Żwirki i Wigury 101, 02-096, Warszawa, Poland.

This is an open-access article distributed under the terms of the Creative Commons Attribution License (for details please see creativecommons.org), which permits unrestricted use, distribution, and reproduction in any medium, provided the original author and source are credited. 
Farf Full text $(1,796.0 \mathrm{kB})$ 